\title{
KONTESTASI IDEOLOGI DALAM SASTRA PRANCIS MASA PERANG DUNIA KEDUA
}

\author{
Wening Udasmoro dan Ali Shahab \\ Fakultas Ilmu Budaya Universitas Gadjah Mada \\ email: weningw@yahoo.com
}

\begin{abstract}
Abstrak
Penelitian ini bertujuan mengeksplorasi kontestasi ideologi pengarang-pengarang Prancis masa Perang Dunia Kedua melalui karya-karya mereka. Sumber data primer dari penelitian ini adalah karya Sartre "Le Mur", karya Albert Camus, "L'Etranger" dan karya Simone Weil, "L'Attente de Dieu". Para pengarang tersebut, di satu sisi memainkan peran sebagai yang menceritakan dunia dengan karya fiksi, di sisi lain berperan aktif dalam pemosisian terhadap ideologi yang diyakini. Penelitian ini menggunakan metode Critical Discourse Analysis. Discourse yang dijelaskan di sini terutama bahwa Tuhan dilihat sebagai bagian dari pengalaman pribadi, sosial dan historis yang dikontestasikan oleh Sartre, Camus dan Weil dalam karya-karyanya. Tuhan dibahas oleh para pengarang dengan perspektif yang berbeda. Hasil dari penelitian ini adalah bahwa Tuhan diposisikan secara filosofis dalam tataran ada dan tidak ada, hadir dan tidak hadir serta pasif dan aktif. Sartre dan Camus berada pada lini yang sama ketika berbicara tentang absennya Tuhan dalam eksistensi manusia. Sementara itu, Simone Weil yang sangat relijius memandang Tuhan hadir secara konkret dalam kehidupan manusia.
\end{abstract}

Kata kunci: kontestasi, ideologi, discourse

\section{CONTESTATION OF IDEOLOGIS IN FRENCH LITERATURE DURING THE ERA OF WORLD WAR II}

\begin{abstract}
This study aims to explore the constestation of French writers' ideologies during the era of World War II through their works. The primary data sources were "Le Mur"by Sartre, "L'Etranger" by Albert Camus, and "L'Attente de Dieu" Simone Weil. On the one hand the writers play roles as ones telling the world through their fiction, but on the other hand they have active roles in positioning their believed ideologies. The study employed the Critical Discourse Analysis method. The discourses emphasize that God is viewed as personal, social, historical experiences contested by Sartre, Camus, and Weil in their works. They discuss God using different perspectives. The findings show that God is philosophically positioned at the levels of being existent and non-existent, present and absent, and active and passive. Sartre and Camus are on the same line when talking about God's absence in human existence. Meanwhile, Simone Weil, who is very religious, views that God is concretely present in human life.
\end{abstract}

Keywords: contestation, ideology, discourse

\section{PENDAHULUAN}

Penelitian ini bertujuan untuk melihat kontestasi ideologi Jean-Paul Sartre, Albert Camus dan Simone Weil dalam karya-karya mereka pada masa sekitar Perang Dunia Kedua. Ideologi mereka dalam konteks ini dilihat sebagai sebuah discourse, yang dalam hal ini didefinisikan bukan sekedar bahasa atau teks tetapi sebagai struktur spesifik dari statemenstatemen, terms, kategori dan kepercayaan yang dikonstruksi secara historis, sosial 
dan institusional. Discourse dalam karya mereka ini tidak sekedar dilihat sebagai rentetan peristiwa dengan penggunaan bahasa dalam konteks komunikatif dan informatif tetapi bahasa sebagai sebuah social practice. Bahasa yang mereka gunakan dalam tulisan-tulisan mereka diasumsikan membentuk dan dibentuk oleh struktur sosial yang berada di sekitarnya. Merujuk pada pendapat Bourdieu (1977) bahwa struktur adalah yang menstrukturkan dan yang distrukturkan, bahasa dalam karya mereka di satu sisi dibentuk oleh sebuah struktur, yakni situasi yang mengiringi penggunaan bahasa tersebut tetapi di sisi lain membentuk struktur yang melingkupinya. Dalam konteks bahasa Jawa, bahasa membentuk kelas sosial tetapi bahasa juga dibentuk oleh kelas sosial. Ideologi adalah salah satu bagian dari struktur tempat bahasa tersebut membentuk dan dibentuk.

Pemosisian terhadap ideologi lewat bahasa yang berbeda ini menjadi penting mengingat bahwa tulisan ketiga pengarang ini menjadi referensi khalayak di Prancis baik dalam tataran epistemologis maupun praksis. Ideologi mereka dibicarakan secara luas di arena publik pada waktu itu. Secara epistemologis, konsep Tuhan misalnya, diperdebatkan dengan sengit oleh ketiganya sehingga seakanakan yang satu menjawab pertanyaan yang lain. Secara praksis, konsep Tuhan dan agama itu pula yang menjadi dasar pertimbangan sekularitas yang sangat kuat di Prancis pada masa kini. Pemosisian terhadap Tuhan dan agama pada waktu itu bukanlah sekedar persoalan manasuka, tetapi bahwa ada discourse yang dikonstruksikan baik secara historis institusional, sosial maupun individual dengan keterlibatan para pengarang Sastra Prancis di dalamnya.

Seperti diketahui, Prancis menganut laicité (pemisahan agama dari negara) sejak awal tahun 1900-an. Ada konteks historis yang terhubung dengan tulisan para pengarang Prancis dalam pemilihan sekularisasi atau relijiusitas merespon epistème atau kaidah laicité tersebut. Sebagai usaha untuk memahami perbedaan ideologi dalam berkarya ini, maka sangat menarik pula untuk melihat discourse sebagai representasi ide personal dan sosial para pengarang terutama dalam hubungannya dengan ideologi yang mereka anut. Konteks resistensi terhadap ideologi yang mereka anut dalam situasi perang yang penuh dengan represi-represi juga penting untuk dilihat.

Perang Dunia Kedua adalah momentum yang menjelaskan bahwa sebuah situasi sosial tertentu seringkali membawa pengaruh yang signifikan terhadap pandangan ideologis pengarang. Pemahaman komprehensif tentang munculnya ideologi-ideologi yang bervariasi akibat situasi dan kondisi sosial dan politik terkait Perang Dunia Kedua perlu dibahas untuk melihat keterhubungan serta gap antara bahasa yang diproduksi dengan praktik sosial ideologi masa tersebut. Bagaimana Tuhan diposisikan dalam kontestasi ideologi ketiga pengarang menjadi fokus dari penelitian ini. Ideologi menjadi satu aspek yang dikontestasikan dalam polemik karya sastra Prancis. Perang Dunia Kedua memunculkan pertanyaanpertanyaan besar di dalam pikiran para pengarang Prancis. Dalam tradisi Prancis, pengarang adalah sumber inspirasi bagi tumbuh kembangnya dunia sosial dan kultural.

Ideologi pengarang pada masa Perang Dunia Kedua, yakni Nasionalisme, Katholisisme, Atheisme, Eksistensialisme dan Komunisme menjelaskan relasi-relasi tertentu. Relasi-relasi tersebut adalah relasi antarsesama manusia dan antara Tuhan dengan manusia. Hubungan-hubungan tersebut dipertentangkan sekaligus dipertautkan secara ketat. Para pengarang menggunakan karya sastra sebagai Champs de Force atau arena pertarungan (Bourdieu, 1977) bagi perbedaan ideologi mereka. 
Dengan demikian, karya sastra menjadi arena pertarungan ideologi yang memberi inspirasi secara langsung maupun tidak langsung terhadap Champs de Force fisik, yakni Perang Dunia Kedua dan perang Spanyol. Jika Champs de Force fisik dapat dikatakan riil, maka karya sastra adalah Champs de Force imajiner. Akan tetapi, Champs de Force imajiner ini merupakan rujukan bagi Champs de Force riil. Namun, terjadi pula bahwa aktor yang sama juga menggunakan dua arena ini sekaligus, misalnya Charles de Gaule yang menggunakan Champs de force imajiner ketika menulis karya sastra dan sekaligus arena kontestasi riil ketika menjadi pemimpin Negara Prancis. Jean-Paul Sartre menggunakan dua arena sekaligus dengan menjadi seorang pejuang pada perang Spanyol dan menjadi penulis yang mengkritisi perang tersebut lewat karyanya. Di satu sisi ada persoalan la littérature engagée, yakni karya sastra yang isinya memperlihatkan pemosisian pengarang secara imajiner dalam tulisannya untuk membela suatu perjuangan. Akan tetapi, menurut penulis, dapat pula dikatakan bahwa ada l'auteur engagé, maksudnya adalah bahwa pengarang betul-betul terlibat tidak hanya dalam Champs de Force imajiner, tetapi juga dalam konteks riil. Pengarang adalah subjek yang turut berpartisipasi dalam pengkonstruksian sebuah pandangan, dan bukan hanya karya sastranya. JeanPaul Sartre adalah contoh jelasnya.

Discourse perbedaan ideologi dalam Champs de Force dapat dikaitkan, dengan persoalan power dan pengalaman pengarang secara individual maupun sosial dalam memahami pemosisian pada ideologi tertentu. Power dalam konteks ini dimaknai sebagai power yang tersebar yang dijalankan oleh mereka yang merasa memiliki kapasitas untuk melakukannya (Foucault, 1966). Sartre, Camus dan Weil menggunakan power mereka sebagai pengarang untuk memproduksi pengetahuan, yang dalam hal ini adalah pemosi- sian terhadap ideologi yang ingin mereka bangun.

Masa sekitar Perang Dunia Kedua membawa refleksi tersendiri terhadap pemosisian ideologi. Relasi antara Tuhan dan manusia menjadi pertanyaan baru yang muncul. Penyokong Katholisisme bertanya, "Dimana seharusnya manusia menempatkan Tuhan ketika melihat sesama mereka saling membunuh dan membantai ?" Sementara itu, penyokong eksistensialisme bertanya, "Perlukah manusia melibatkan Tuhan untuk memutuskan perang ?" Atau, "Perlukan intervensi Tuhan dalam memutuskan perang?" Penganut Atheisme akan bertanya, "Perlu Tuhankah manusia dalam kehidupannya." Sementara itu penyokong nasionalis akan bertanya, "Tuhan seperti apa yang negara butuhkan?" Discourse yang berbeda tersebut saling berkompetisi dan bertarung lewat karya-karya sastra ketiga penulis besar Prancis tersebut.

Pendefinisian hubungan antara Tuhan dengan manusia kemudian memunculkan resistensi-resistensi terhadap ideologi yang lain. Pengalaman individual dan sosial berpengaruh besar terhadap pemosisian ideologi ini. Resistensi-resistensi ini muncul sebagai akibat perasaan terancam akan keberadaan atau kemunculan ideologi yang lain. Gerakan eksistensialisme dan Atheisme, misalnya, dianggap sebagai discourse ancaman bagi penganut Katholisisme karena akan mengarahkan dunia pada sekularisasi yang berdampak pada degradasi moralitas. Sementara itu, bagi atheisme, justru discourse teologies dan agamis inilah yang mereka anggap membawa persoalan bagi independensi manusia dalam berpikir dan bertindak. Terjadilah challenge and response antara discourse ideologi yang satu dengan yang lain.

\section{METODE}

Objek material primer dalam penelitian ini adalah Le Mur karya Sartre (1942), 
L'Etranger karya Albert Camus (1942) dan L'Attente de Dieu karya Simone Weil. (1952). Sementara itu, untuk memahami perspektif ideologi ketiga pengarang tersebut, karya-karya filosofis mereka menjadi data sekunder dalam penelitian, yakni L'Etre et le Néant (1943) dan L'Existentialisme est un Humanisme karya Sartre (1946), Le Myth de Sisyphe (1942) dan la Peste karya Camus (1947) serta La Condition Ouvrière karya Simone Weil (1952).

Penelitian ini menggunakan metode Critical Discourse Analysis (Fairclough, 1992; 1997) yang mencoba mengungkapkan ideologi yang ada dalam mental model para pengarang yang berbeda untuk mendapatkan perspektif mereka terkait berbagai persoalan yang muncul pada waktu itu, yakni Perang Dunia Kedua serta Perang Spanyol. Meskipun kontestasi dilakukan oleh pengarang yang berbeda, satu aspek, yakni konsep tentang Tuhan menjadi fokus.

Metode ini dilakukan dengan cara mencari keterhubungan antara linguistic practice (teks), discursive practice (discourse) dan social practice (konteks) terkait dengan perspektif pengarang yang tercermin baik dari karya sastra maupun dari argumen pribadi yang mereka kemukakan. Keterhubungan dilakukan dengan membongkar discoursive practice mereka, yakni bentuk-bentuk pemahaman dan pendefinisian terhadap Tuhan serta persoalan relijiusitas lain yang merupakan konsumsi-konsumsi teks-teks (agama, gereja, negara, dogma, dan rujukan terhadap pengarang lain dsb) yang menjadi bahan acuan dalam berpikir mereka.

Setiap pengarang dilihat perspektif mereka dalam hubungannya dengan discourse terkait ideologi mereka. Ada tiga tahapan yang dilakukan dalam analisis terhadap perspektif para aktor. Pertama adalah melihat discourse sebagai teks bahasa yang oleh Fairclough (1992; 1997) disebutnya dengan tataran mikro, yang merupakan bentuk deskripsi terhadap teks yang diungkapkan oleh seseorang. Pada tataran ini (Fairclough, 1992; Wijsen, 2010) dilakukan analisis terhadap bahasa (linguistic practice) yang digunakan oleh ketiga pengarang tersebut. Tataran ini menjadi awalan yang penting karena bahasa di satu sisi adalah shared meaning akan tetapi di sisi lain adalah produksi individual yang terkait erat dengan siapa yang berbicara, kapan dan dimana serta dalam posisi sebagai apa orang berbicara. Sebagai contoh, pemilihan kata-kata atau wording seringkali menunjukkan pemosisian seseorang terhadap yang lain. Jihad, misalnya, oleh satu kelompok seringkali dilihat sebagai bentuk sacrifice untuk tujuan pembelaan diri yang dalam refleksi teologis bermakna untuk kebaikan seluruh umat. Akan tetapi, jihad bagi kelompok yang lain seringkali diartikan sebagai pembelaan membabi buta untuk tujuan ideologis tertentu.

Dalam metode pertama ini, analisis terhadap teks linguistik difokuskan pada wording, alternative wording serta struktur gramatikal teks (Fairclough, 1992; 1997). Pertanyaan yang diajukan adalah bagaimana ketiga pengarang yang berbeda tersebut berbicara tentang Tuhan dan relijiusitas? Wording dan alternative wording apa yang digunakan? Bagaimana persoalan ideologi digunakan dalam teksteks mereka?

Tataran kedua adalah melihat discourse sebagai discursive practice (interaksi). Discourse adalah bentuk interaksi antara satu orang dengan yang lain. Pada tataran ini, ditunjukkan bentuk-bentuk interpretasi, atau yang disebut Fairclough sebagai tataran mezzo yang menjelaskan konsumsi dan reproduksi teks yang dilakukan oleh ketiga pengarang yang berbeda. Pada tahap interpretasi ini, hal yang penting ditekankan adalah bahwa interpretasi yang dimaksud bukanlah interpretasi peneliti terhadap yang dikatakan aktor sosial tetapi apa interpretasi pengarang tersebut terhadap persoalan ideologi. 
Konsumsi teks dilakukan setelah melampaui proses kognisi (cognitive process) dan proses pembiasaan (habituation process) dalam habitus para pengarang sehingga wording, alternative wording serta struktur gramatikal yang dipilih dan digunakan mencerminkan konsumsi teks tersebut. Intertekstualitas dan interdiscursivity sebagai cermin konsumsi dan reproduksi teks menjadi aspek-aspek penting dalam tataran ini.

Dalam tataran interpretasi yang merupakan analisis terhadap produksi, distribusi dan konsumsi terhadap teks ini, Fairclough (1992; 1997) juga menawarkan beberapa tools. Dalam tulisan ini, intertekstuality akan digunakan dalam analisis, yakni intekstualitas apa yang dijadikan referensi oleh para pengarang untuk berpendapat. Pertanyaan analitis yang dapat muncul adalah bagaimana discourse yang satu berhubungan dengan discourse yang lain? Adakah order of discourse yang muncul atau adakah disorder of discourse yang muncul?

Analisis tataran ketiga adalah dengan melihat discourse sebagai social practice yang memberi tekanan pada persoalan power (terutama hegemoni) serta ideologi yang dipraktikkan. Critical Discourse Analysis memiliki fokus utama pada penelusuran "explanation connection" (Wijsen, 2010: 2) antara penggunaan bahasa (discourse) dan social reality (structure). Menurut Wijsen (2010: 2) yang mendalami pendekatan Fairclough ini, Fairclough memulai dari asumsi-asumsi bahwa, pertama, discourse adalah sebuah praktik, seperti halnya praktik-praktik yang lain. Kedua, ada relasi dialektik antara discourse dan realita. Ketiga, relasi antara discourse dan realita dimediasi oleh discursive practice. Tahapan ketiga adalah social practice atau yang disebut Fairclough dengan tataran eksplanasi. Tataran ini menjelaskan konstruksi sosial yang dihubungkan dengan persoalan power dan ideologi sosial yang diaplikasikan dalam masyarakat.
Tataran eksplanasi merupakan analisis efek sosio-kognitif teks. Fairclough (1992; 1997) menyebutkan berbagai variasi tools yang dapat digunakan. Fokus yang ada dalam hal ini adalah persoalan ideologi. Pertanyaan yang dapat dimunculkan adalah apa hubungan antara bahasa yang digunakan dengan realitas sosial dalam persoalan ideologi? Apakah hal-hal tersebut itu direproduksi atau ditransformasi oleh para aktor tersebut?

\section{HASIL DAN PEMBAHASAN Paradoksalitas Sartre dalam Konsep Ma- nusia Mengada, Sendiri dan Bebas}

Ketiga ideologi di atas menjadi hal penting yang dicoba untuk dikemukakan oleh tiga pengarang dengan perspektif yang berbeda. Tabu mempertanyaan agama sudah luntur sejak tradisi Marxisme menguat pada abad ke-19. Namun, apabila pada waktu itu kapitalisme menjadi aspek yang dikontraskan dengan agama, seperti yang dilakukan oleh Marx, yakni agama sebagai product of alienation atau produk alienasi, Durkheim (1965) agama memiliki fungsi untuk binding togetherness atau mempererat kebersamaan. Weber (1958) yang melihat agama sebagai sesuatu yang kreatif maka pada abad tengah abad ke-20 mereka bukan lagi merespon kapitalisme. Yang direspon oleh ketiga pengarang adalah Perang Dunia Kedua dengan aspek-aspek pengaruhnya terhadap kemanusiaan. Yang dipertanyakan bukan posisi agama vis-àvis kapitalisme tetapi keberadaan Tuhan. Gereja bukan merupakan institusi yang ingin digedor-gedor eksistensinya karena hal tersebut sudah terjadi dan dilakukan pada satu abad sebelumnya. Yang sekarang ditekankan adalah hubungan manusia dengan Tuhan. Perang Dunia Kedua menjadi momentum penting karena para filsuf mulai bertanya « mengapa manusiamanusia yang mengklaim diri percaya pada Tuhan melakukan bentuk-bentuk opresi terhadap yang lain ». 
Dalam kumpulan karyanya berjudul Le Mur (Tembok), Sartre (1942) menunjukkan absurditas terutama terkait dengan keberadaan Tuhan tersebut. Albert Camus (1942) melakukan hal yang sama ketika menulis l'Etranger (Orang Asing). Sementara itu, Simone Weil (1952) dalam l'Attente de Dieu (Penantian Tuhan) justru mengemukakan pentingnya Tuhan. Secara spesifik, apa yang dijelaskan oleh ketiganya tentang posisi diri dengan Tuhan dalam konteks karya-karya mereka?

Sartre terkenal dengan pandangannya tentang eksitensialisme. Dalam tulisantulisan Sartre seperti Le Diable et le Bon Dieu (Setan dan Tuhan yang Baik), L'Etre et le Neant (Mengada dan Melahirkan), L'existentialisme est un humanisme (Eksistensialisme adalah Humanisme) serta dalam karya-karya romannya seperti Le Mur (Tembok) atau Les Mots (Kata-Kata), ada bentuk-bentuk kekonsistenan yang dibicarakan oleh Sartre sebagai usaha untuk mendeklarasikan eksistensialismenya yang berbeda sekaligus sama dengan bentuk eksistensialisme penulis dan filsuf yang lain, misalnya Frederich Nietsze atau Heidegger. Bentuk-bentuk pemikiran yang konsisten tersebut terlihat dari discourse yang dia bangun untuk mengkonstruksi perspektifnya tentang eksistensialisme tersebut. Dalam tataran linguistic practice, beberapa wording seringkali digunakan terkait dengan Tuhan dan ideologi eksistensialisme tersebut. Kebebasan seringkali digunakan sebagai alternative wording untuk menjelaskan hubungan antara manusia dengan Tuhan. Mengenai kebebasan Sartre mengatakan :

«Il n'y a pas de Dieu, l'homme est seul et libre, il est par conséquant responsable de lui-même et des autres.»

Tuhan tidak ada, manusia sendiri dan bebas, sebagai akibatnya ia bertanggung jawab terhadap diri dan yang lain.
Ia juga berpendapat :

"L'Homme n'est rien d'autre que ce qu'il se fait. Tel est le premier principe de l'existentialisme».

Manusia berarti apa yang dia lakukan. Ini adalah prinsip utama eksistensialisme

Sartre memilih wording seul (sendiri) dan libre (bebas) dalam teksnya tersebut. Dieu (Tuhan) disebut tetapi untuk diabsenkan dengan penggunaan kata il n'y a pas (tidak ada). Selain itu, kata lui-meme (dirinya sendiri) dan des autres (yang lain) mewarnai argumen-argumennya.

Sendiri dan bebas ini kemudian menjadi paradoksal ketika dia mengemukakan tentang wording responsable (bertanggung jawab). Dalam kata bertanggung jawab tersebut ada tanggung jawab untuk yang lain (les autres). Namun, paradoksalitas tersebut menjadi memungkinkan dilakukan karena discourse Sartre bergerak antara pemosisian diri, orang lain dan Tuhan yang menempatkan "diri" sebagai sentral dari orientasi-orientasi dan meletakkan "yang lain" dan "Tuhan" dalam periferi. Dengan kata lain, pembebasan diri hanya dapat dilakukan menurut Sartre, dengan tidak melibatkan (meniadakan) Tuhan. Sementara itu, orang lain hanya menjadi efek dari yang dilakukan oleh individu.

Dalam karya-karyanya antara lain, l'Etre et le Neant, Sartre berpendapat terkait dengan filsafat eksistensialisme :

"Les uns disaient qu'elle plongeait les hommes dans le désespoir car elle enlevait tout sense au monde et à l'existence individuelle. Les autres disaient qu'en niant Dieu et les valeurs superieurs, elle conduisait à l'immoralité et à l'anarchie.»

Orang-orang (yang satu) mengatakan bahwa eksistensialisme menenggelamkan manusia pada kekecewaan karena penyerobotan seluruh makna 
pada dunia dan pada eksistensi individu. Orang yang lain mengatakan bahwa dengan meniadakan Tuhan dan nilai-nilai keilahian, eksistensialisme membawa pada imoralitas dan anarki.

Dalam kalimat tersebut, kembali Sartre menggunakan dikotomi-dikotomi. Les uns (orang yang satu) dan les autres (orang yang lain) dia kontraskan. Kembali kontras tersebut melibatkan individu, les hommes atau manusia (secara kolektif) dan Tuhan. Ada dikotomi yang sangat erat terkait antara les uns dan les autres yang sebenarnya berimplikasi bahwa pendapat tersebut dapat dikatakan oleh siapa saja. Filsafat eksistensialisme diakuinya membawa orang pada paradoksalitas dengan adanya tarik menarik antara individu dan manusia secara umum ketika berbicara tentang eksistensi manusia dan keberadaan Tuhan. Ada sementara orang yang melihat eksistensialisme sebagai discourse kebebasan. Sementara itu, ketika berbicara tentang Tuhan, les autres merupakan agen yang tidak menyetujui eksistensialisme yang meniadakan Tuhan karena dianggap membawa pada imoralitas dan anarkisme.

Dalam l'Existentialisme est un humanisme dia juga menulis:

«L'homme etant condamné à être libre porte le poids du monde tout entier sur les épaules: il est responsable du monde et de lui-même en tant que manière d'être.

"L'homme tel quele concoitl'existentialiste, s'il n'est pas definissable, c'est qu'il n'est d'abord rien. Il ne sera qu'ensuite, et il sera tel qu'il sera fait. Ainsi, Il n'y a pas de nature humaine, puisqu'il n'y a pas de Dieu pour la concevoir. L'homme est seulement, non seulement tel qu'il se concoit, mais tel qu'il se veut».

Manusia sebagai yang dihukum untuk menjadi bebas menanggung beban dunia di pundaknya: ia bertanggung jawab pada dunia dan dirinya sendiri sebagai makhluk.

Manusia menurut eksistensialisme, jika dia tidak dapat didefinisikan mula-mula dia bukanlah apa-apa. Kemudian, ia akan menjadi seperti apa yang ia lakukan. Maka, tidak ada manusia yang natural, karena Tuhan tidak ada untuk membuatnya. Manusia bukan apa yang dibuat tetapi apa yang dia inginkan.

Kata condamné à être libre (dihukum untuk menjadi bebas) menunjukkan paradoksalitas yang lain. Dihukum biasanya dikaitkan dengan ketidakbebasan. Orang dihukum untuk menjadi tidak bebas. Akan tetapi, dalam opini Sartre justru sebaliknya. Yang menjadi persoalan, Sartre menggunaan bentuk pasif di sini. L'homme est condamné à être libre (manusia dihukum untuk bebas). Bahasa Prancis, tidak seperti bahasa Indonesia, pada dasarnya lebih mengedepankan bentuk aktif daripada pasif. Passive voice sangat dihindari dalam bahasa Prancis karena dinilai meniadakan subjek. Ketika Sartre mengatakan kalimat di atas maka pertanyaannya, siapa subjeknya? Siapa yang menghukum manusia? Kembali paradoksalitas di sini muncul. Sartre sebetulnya sedang berbicara tentang Tuhan tetapi Tuhan untuk diabsenkan demi tujuan kebebasan manusia. Dia meniadakan Tuhan secara eksplisit meskipun secara implisit justru masih mengakui keberadaanya.

Paradoksalitas yang lain adalah ketika dia mengatakan bahwa manusia dihukum untuk menjadi bebas sehingga seluruh beban dunia berada di pundaknya. Ketika manusia bebas, mengapa dia menanggung beban dunia? Untuk menjelaskan hal tersebut, kata bertanggung jawab (responsible) menjadi jawabannya. Orang bebas sehingga dia memiliki beban untuk bertanggung jawab terhadap diri sendiri dan 
dunia. Tuhan kembali ditiadakan. Bentukbentuk konstruktivisme dimunculkan dengan mengedepankan manusia sebagai subjek ketika dia mengatakan: tel qu'il se veut (ketika ia menginginkannya).

Dalam menulis karya sastranya, Sartre merujuk pada ideologinya sendiri, yakni eksistensialisme. Namun, ideologi eksistensialisme ini tentu saja tidak dapat dilepaskan dari ideologi eksistensialis yang lain, terutama Nietsze. Hal yang paling menonjol adalah pertanyaan tentang Tuhan. Namun, perbedaannya Sartre lebih mengabsenkan Tuhan sedangkan Nietsze mematikan Tuhan.

Tiadanya Tuhan ditunjukkan dengan mengulang-ulang wording Tuhan dalam kalimat-kalimatnya ketika menjelaskan eksistensialisme. Ada intertekstualitas pada perspektif agama dalam tulisannya meskipun hal tersebut melawan konsep normativisme tersebut. Dia misalnya mengatakan:

"l'existentialisme pense qu'il est très génant que Dieu n'existe pas, car avec lui disparait toute possibilité de trouver des valeurs dans un ciel intelligible; il ne peut plus trouver y avoir de valeur de bien a priori puisqu'il n'y a pas de conscience infinie et parfaite pour le penser»

Eksistensialisme berpikir bahwa sangat tidak mengenakkan bahwa Tuhan tidak eksis karena denganNya hilanglah seluruh kemungkinan untuk menemukan nilai-nilai di langit yang dapat dipahami; tidak bisa lagi ditemukan di situ nilai yang apriori karena tidak adanya kesadaran yang tanpa batas dan sempurna untuk memikirkannya.

Secara makro, atau dalam praktik sosial, kebebasan menjadi aspek yang dipraktikkan oleh Sartre. Konsisten dengan kebebasan yang diideologisasikan dalam pandangan-pandangannya, Sartre menolak hadiah nobel yang diberikannya pada tahun 1960-an. Meniadakan Tuhan dilakukannya dalam praktik dengan menjadi atheis dan tidak menikah. Berafiliasi pada institusi keagamaan dan perkawinan dianggapnya mengekang kebebasanya. Praktik tanggung jawab kepada orang lain yang selalu diulangnya ditunjukkan dengan cara menjadi militant dan bahkan sampai ikut terjun langsung terlibat secara fisik dalam perang Spanyol.

Dalam praktik sosial, yang dijelaskan Sartre tentang kebebasan juga bersifat paradoksal. Dia berbicara tentang kebebasan tetapi memberikan legitimasi pada praktik-praktik kolonialisme.

\section{Pandangan Metaforik Camus terhadap Tuhan}

Sementara itu, karya-karya monumental Albert Camus antara lain adalah l'Etranger (Orang Asing), La Peste (pes), Le Mythe de Sisyphe (Mitos Sisispus), La Chute (Keterpurukan) dan L'Homme Revolté (Manusia Pemberontak). Meskipun Sartre dan Camus adalah filsuf eksistensialis, akan tetapi keduanya memiliki pandangan yang agak berbeda tentang Tuhan dilihat dari discourse yang mereka produksi. Dalam Le Myth de Sisyphe, Camus (1942) mengatakan tentang Tuhan sebagai berikut:

“Où est passé Dieu? Je vais vous le dire! Nous l'avons tué, vous et moi! Nous sommes tous ses assassins! Mais comment avons-nous fait cela? (...) Est-il encore un haut et un bas? N'errons-nous pas comme à travers un néant infini? L'espace vide ne répand-il pas son souffle sur nous? Ne s'est-il pas mis à faire plus froid? La nuit ne tombe-t-elle pas continuellement?

«Kemana perginya Tuhan? Akan saya katakan pada kalian! Kita telah membunuhnya, kalian dan saya! Kita semua adalah pembunuh! Tapi bagaimana kita melakukannya? (...) Masih adalah pasang surut? Tidakkah kita sedang melewati kehampaan yang 
tanpa akhir? Ruang hampa tidakkah memberikan helaan angin pada kita? Tidakkah membuat cuaca lebih dingin? Malam tidakkah turun terus menerus?

Camus menggunakan pemilihan kata nous l'avons tué (kita sudah membunuhnya) untuk menggambarkan Dieu dan yang membunuh adalah vous (anda) dan moi (saya). Ada konteks subjektivitas yang jelas dari vous et moi atau anda dan saya. Hal ini yang tidak terdapat dalam konteks Sartre. Dalam Sartre, yang muncul adalah il n'y a pas de Dieu. Kata il n'y a pas (tidak ada) menunjukkan bahwa ketiadaan Dieu bukan karena dibunuh tetapi secara Natural tidak ada sehingga memperkuat asumsi bahwa Tuhan sebetulnya masih ada bagi Sartre meskipun tidak present atau tidak eksis dalam kehidupan manusia. Dengan demikian, ada kedekatan antara saya (diri) dan kamu (yang lain) yang dalam konteks Sartre dipisahkan. Dalam Sartre ada pembedaan mendasar antara saya, yang lain dan Tuhan dengan saya sebagai center atau sebagai yang bertanggung jawab terhadap yang lain. Sementara itu, dalam Albet Camus, saya dan yang lain (vous) atau anda dalam hal ini bukan entitas yang terpisah atau dependent antara yang satu dengan yang lain. Keduanya bersekongkol membunuh Tuhan.

Dalam l'Etranger Camus ketika Camus menggambarkan tokoh utama Merseult, dengan menuliskan:

"Il y a quelque chose qui a crevé en moi. Je me suis mis à crier à plein gosier et je l'ai insulté et je lui ai dit de ne pas prier.

"Ada sesuatu yang menyesakkanku. Aku berteriak kegirangan dan aku menghinanya dan kukatakan padanya untuk tidak usah berdoa.

Eksistensialisme Atheis muncul kuat dalam pandangan Camus yang hadir da- lam bentuk-bentuk pemilihan kata yang mencoba menolak praktik-praktik spiritual. Je lui ai dit de ne pas prier (saya menyuruhnya untuk tidak berdoa) menjelaskan satu pemilihan bahasa yang menjelaskan praktik kehidupan spiritualitas seseorang terhadap Tuhan. Dalam salah satu percakapan dalam la Peste juga dituliskan :

Croyez-vous en Dieu, docteur? (...) - Non, mais qu'est-ce que cela veut dire? (...)". Pour lui, l'amour de Dieu est en effet "un amour difficile", il exige "l'abandon total de soi-même et le dédain de sa personne $(\ldots)^{\prime \prime}$

Apakah anda percaya pada Tuhan, dokter? (...) - Tidak, tapi apa maksudnya? Bagi dia, cinta Tuhan adalah «cinta yang sulit», dia menekankan "meninggalkan secara total dirinya dan dari dalam dirinya (...)

Dalam pemilihan bentuk negatif dengan kata «non» secara terbuka serta bagaimana kata cinta terhadap Tuhan dianggap sebagai suatu hal yang sulit dalam diri seseorang menunjukkan penentangan psikologis dari ideologi Camus ketika berbicara tentang Tuhan.

Sementara itu dalam La Chute, dia menuliskan,

Je verrais plutôt la religion comme une grande entreprise de blanchissage (...)"

Saya lebih melihat agama sebagai sebuah perusahaan pemutihan yang besar.

Dari contoh-contoh wacana tentang Tuhan di atas terlihat bahwa keberadaan Tuhan diperdebatkan dengan keberadaan manusia. Agama juga dibendakan dan dimetaforkan dengan sebuah perusahaan pemutihan (laundry). Dalam konteks ini, wording yang dipilh Camus bersifat metaforik. 
Dalam tataran diskursif, karya-karya Camus merujuk pada pengalaman individunya terhadap sud profond, yakni negara magreb tempat dia dibesarkan. Pemosisian terhadap sud profond ini terlihat dari karya-karyanya, antara lain l'Etranger.

Secara praktik sosial, Camus adalah juga seorang jurnalis militan (engagé) yang melakukan tindakan-tindakan resistensi pada masa setelah perang Dunia Kedua. Ia mengkritisi totelitariesme Soviet dan banyak berseberangan ide dengan Sartre dalam hal ini. Ia menentang kolonialisme Prancis di Aljazair.

\section{Pandangan Relijius Weil dan Tuhan se- bagai Sumber Kehendak}

Pengarang ketiga yang melihat Tuhan dengan cara lain adalah Simone Weil. Simone Adolphine Weil adalah seorang pengarang besar Prancis yang mengalami peristiwa dua Perang Dunia, yakni pertama dan kedua. Dia lahir pada tanggal 3 Januari 1909 dan meninggal pada tahun 1943. Dalam pendidikannya, dia belajar filsafat Kristen dan Eksistensialisme Kristen. Karya-karya yang pernah dihasilkannya antara lain adalah $\mathrm{La}$ Condition Ouvrière (Kondisi Pekerja), Reflexion sur la cause de la liberte et de l'opression sociale (Refleksi terhadap Penyebab Kebebasan dan Opresi Sosial), la Pesanteur et la Grace, l'Enracinement dan l'Attente de Dieu (Penantian Tuhan).

Sejak tahun 1938 Simone Weil cenderung menulis terkait dengan Tuhan dan mendekatkan diri pada Kristianisme. Secara praktik ia juga dekat dengan para pemimpin agama dan pastor terutama untuk menanyakan hal-hal terkait Agama Katholik. Simone Weil adalah seorang Yahudi yang pada masa hidupnya mengalami peristiwa yang menimpa orangorang Yahudi di Eropa. Ketika Paris dideklarasikan sebagai "ville ouverte" (kota terbuka) dia dan keluarganya melarikan diri ke Marseille.
Tuhan oleh Weil dalam kontestasi ideologi justru diletakkan pada discourse spiritual yang sangat penting. Dalam bukunya l'Attente de Dieu (Penantian Tuhan), kata-kata l'Amour de Dieu (cinta Tuhan) muncul secara terus menerus menunjukkan bahwa kata l'Amour de Dieu yang menurut Camus bersifat sangat sulit justru sebaliknya dalam pemahaman Weil. Hal ini bisa dimengerti, sebagai seorang Yahudi yang dikejar-kejar pada masa holocaust dan berhasil lepas dari pengejaran tersebut menumbuhkan perasaan spiritual akan hadirnya cinta Tuhan dalam diri Simone Weil.

Dalam l'Attente de Dieu dia menuliskan:

Tout se qui se produit est en fait la volonte de Dieu, sans aucune exception

Semua yang terjadi adalah kehendak Tuhan, tanpa pengecualian

Wording yang dipilih dalam hal ini adalah kehendak (la volonté) dimana Tuhan dalam hal ini lebih menjadi subjek. Bila dalam Sartre dan Camus Tuhan lebih sebagai objek dan manusia sebagai yang mengkonstruksi (subjek), dalam karya Weil, pemilihan wording dengan tout se qui se produit (semua yang terjadi) ditunjukkan dengan bentuk pasif. Pemasifan ini meniadakan manusia sebagai subjek aktif sehingga ada entitas lain sebagai subjek, yakni Tuhan. Yang terjadi adalah pada manusia yang di situ diobjekkan oleh Weil.

Tulisan ini menunjukkan arah yang sangat berlawanan dengan Sartre dan Camus yang justru sebaliknya menjelaskan bahwa Tuhan sama sekali tidak terlibat pada apa yang terjadi di dunia ini. Semua adalah kehendak manusia.

Weil juga mengatakan :

Autrement dit, Il faut sentir la realité et présence de Dieu à travers toutes les choses exterieures sans exception ... 
Dengan kata lain, harus dirasakan kenyataan dan kehadiran Tuhan lewat segala hal di luar tanpa pengecualian.

Kembali dalam kalimat di atas Weil memasifkan manusia dengan memilih alternative wording il faut sentir la réalité et la presence de Dieu. Kalimat ini tidak menggunakan kalimat aktif yang mensubjekkan manusia. Kehadiran Tuhan diletakkan tidak saja pada tataran abstrak tetapi bahkan pada tataran riil yang dalam konteks ini tidak terdapat dalam pemikiran Sartre dan Camus.

Jika dalam tulisan Camus berdoa sebagai praktik relijius dan spiritual dinihilkan, justru sebaliknya dalam l'Attente de Dieu. Weil (1952) mengatakan :

Dieu recompense l'ame quipense à lui avec attention et amour

Tuhan memberi hadiah pada jiwa yang memikirkanNya dengan perhatian dan cinta.

Tuhan dilihat bukan sebagai sesuatu yang tidak ada (il n'y a pas) seperti dalam konteks Sartre atau (tué atau dibunuh) dalam konteks Camus, tetapi sebagai yang Hadir secara aktif memberikan cinta pada manusia yang mencintaiNya.

Dalam tataran diskursif, pengalaman sebagai orang Yahudi yang marjinal mewarnai pergulatan ideologi dalam karyakaryanya yang secara langsung teraplikasikan juga dalam tataran praktis. Secara praktik, Weil adalah penganut Katolik yang sangat taat. Pengalaman sebagai orang Yahudi yang dikejar-kejar pada masa Nazi menjadikan Weil semakin dekat dan mengapresiasi keberadaan Tuhan. Kehadiran Tuhan dianggap Weil merupakan bagian dari pengalaman diri yang penting yang menyebabkannya lepas dari kejaran tentara Nazi.

\section{SIMPULAN}

Dari uraian di atas terlihat bahwa ketiga pengarang mendefinisikan Tuhan dengan cara yang berbeda. Tuhan berada dalam tataran ada dan tidak ada, hadir dan tidak hadir serta pasif dan aktif. Sartre dan Camus berada pada lini yang sama ketika berbicara tentang absennya manusia dalam eksistensi mereka dibandingkan dengan Weil yang sangat reijius memandang Tuhan secara konkrit. Akan tetapi kontestasi ideologi Camus dan Sartre terilhat dari cara pandang mereka ketika berbicara tentang Tuhan dalam konteks diri dan yang lain. Sartre tampak membedakan diri dengan yang lain secara ketat sehingga jargonnya "l'envers c'est les autres" atau neraka adalah orang lain menjadi sangat wajar menjelaskan hal tersebut. Sementara itu, Camus mengkooperasikan hubungan diri dan yang lain dalam tulisannya sebagai yang bertanggung jawab akan kematian Tuhan atau terbunuhnya Tuhan.

Lingkungan budaya Sartre (individualis) sebagai seorang Prancis dan latar belakang sosial Camus sebagai pied noir atau orang kulit putih yang besar di Afrika menjelaskan hal tersebut. Sementara itu, latar belakang sosial sebagai orang Yahudi yang dikejar-kejar Nazi Jerman menempatkan Weil sebagai yang berposisi terhadap keberadaan Tuhan dengan mengedepankan cinta Tuhan dalam tulisannya. Afiliasi Weil pada Katholisisme adalah afiliasi strategis sebagai anggota kelompok marjinal dalam konteks Eropa. Bagi Sartre yang berasal dari kelompok dominan, yakni Eropa, kulit putih dan bertradisi Kristen, strategi seperti itu justru tidak dibutuhkan. Menjadi berbeda dalam pandangan-pandangannya justru menjadi strategi Sartre untuk eksis dalam kancah sastra Prancis.

Pengkontestasian terhadap keberadaan Tuhan tersebut memiliki efek sosial yang cukup penting dalam kehidupan sastra dan kehidupan sosial di Prancis 
pada masa itu. Discourse yang dibangun ketiganya merupakan pemosisian individual tetapi memiliki dampak sosial yang sangat tinggi terutama pada tengah abad ke-20. Tuhan yang dipertanyakan menjadi diskusi terus menerus secara sastra, sosial dan politik dan aspek-aspek pemikiran ketiganya menjadi discourse yang dijadikan rujukan oleh komponen-komponen sosial yang berbeda. Tuhan yang dikontestasikan dalam hal ini terkait dengan pengalaman individu, sosial dan historis masing-masing pengarang. Keterikatan para pengarang pada institusi dan sosial tertentu berpengaruh secara signifikan pada pandangan spiritual mereka terhadap Tuhan.

\section{UCAPAN TERIMA KASIH}

Penelitian ini adalah hasil Hibah penelitian dari Program Studi Sastra Prancis pada tahun 2011. Ucapan terima kasih ditujukan kepada kolega-kolega Jurusan Sastra Prancis Universitas Gadjah Mada yang telah membantu dengan diskusidiskusi yang membangun.

\section{DAFTAR PUSTAKA}

Bourdieu, Pierre. 1977. Outline of a Theory of Practice, Cambridge: Cambridge University Press.

Camus, Albert. 1942. L'Etranger. Paris: Gallimard
Camus, Albert. 1942. Le Myth de Sisyphe. Paris: Folio

Camus, Albert. 1947. La Peste. Paris: Gallimard

Durkheim, Emile. 1965. The Elementary Forms of the Religious Life, New York: Free Press

Fairclough, Norman. 1992. Language and Power. London \& New York:Longman

Fairclough, Norman. 1997. Critical Discourse Analysis: The Critical Study of Language. London \& New York: Longman

Foucault, Michel. 1966. Histoire de la Sexualité. Paris: Gallimard

Sartre, Jean-Paul. 1964. Les Mots. Paris : Gallimard

Sartre, Jean-Paul. 1946. L'existentialism est un humanisme. Paris: Edition Nagel

Sartre, Jean-Paul. 1943. L'Etre et le Neant, Paris: Gallimard

Sartre, Jean-Paul. 1939. Le Mur. Paris: Folio

Weber, Max. 1958. The Protestant Ethic \& the Spirit of Capitalism. Translated by Talcott Parsons. New York: Scribner.

Weil, Simone. 1952. Condition Ouvrière. Paris: Folio

Weil, Simone. 1952. L'Attente de Dieu. Paris: Fayard

Wijsen, Frans. 2010. "Discourse Analysis in Religious Studies: The Case of Interreligious Worship in Friesland" In Anthropos Volume 105, hlm 1-15 